\title{
Two new species of phthiracaroid mites (Acari, Oribatida, Phthiracaroidea, Steganacaridae) from Australia
}

\author{
Wojciech NiEDBALA \\ Department of Animal Taxonomy and Ecology, Faculty of Biology, Adam Mickiewicz University, Umultowska 89, \\ 61-614 Poznan, Poland; e-mail: wojciech.niedbala@amu.edu.pl
}

\begin{abstract}
Descriptions of two new species of phthiracaroid ptyctimous mites Plonaphacarus trojani sp. nov. and Notophthiracarus trojani n. sp. from Australia are dedicated to an oustanding Polish ecologist and entomologist Professor Przemysław Trojan at his 80th birthday.
\end{abstract}

Key words: Acari, Oribatid mites, Phthiracaroidea, new species

\section{INTRODUCTION}

Ptyctimous mites are a special group of Oribatida (Norton \& Behan-Pelletier 2009) ptychoid body form, and charactersied by the ability of folding propodosoma close to opisthosoma in order to protect the ventral region and appendages.

Two new species described below belong to two different genera of family Steganacaridae Niedbała, 1986: Plonaphacarus Niedbala, 1986 and Notophthiracarus Ramsay, 1966.

Notophthiracarus is the genus most abundant in Australia and comprises over 60 species, however, the genus Plonaphacarus is represented only by nine species (Niedbała 2000, 2006). Both are typical of southern hemisphere.

The species are named in honour of Professor Przemysław Trojan, an outstanding ecologist and zoologist, entomologist, at his 80th birthday .

\section{DESCRIPTIONS OF SPECIES}

\section{Plonaphacarus trojani sp. nov.} (Figs 1-7)

Description. Measurements of holotype: prodorsum: length 374, width 268, height 126 , sensillus 136, setae: interlamellar 353, lamellar 303, rostral 151, exobothridial 50; notogaster: length 707, width 405 , height 434, setae: $c_{1} 425, h_{1} 454, p_{1} 444$; genitoaggenital plate $151 \times 156$, anoadanal plate $293 \times 187$.

Colour brown. Surface of body covered with coarse structure but not foveolate.

Prodorsum without lateral carinae. Sigillar fields weakly visible, median shorter than laterals. Sensilli similar to interlamellar setae, long, with flagelliform distal end, sparsely covered with cilia. Interlamellar setae also flagelliform but lamellar and rostral setae pointed distally, rostral setae rigid. Notogaster with 15 pairs of very long, thick setae, majority of them flagellate distally but setae $d_{1}, d_{2}, e_{1}, e_{2}, h_{3}, p_{3}$ pointed distally. All setae sparsely covered with small spines. Setae $c_{1}$ and $c_{3}$ located at anterior margin, setae $c_{2}$ slightly remote from border. Vestigial setae not visible. Two pairs of lyrifissures ia, im present. Ventral region. Setae $h$ of mentum as long as distance between them. Formula of genital setae: 4+2: 3. Anoadanal plates with 5 pairs of long setae covered with cilia. Setae $a d_{1}$ and $a d_{2}$ longer than other setae. Only setae $\mathrm{ad}_{3}$ pointed distally, other setae flagellate. 


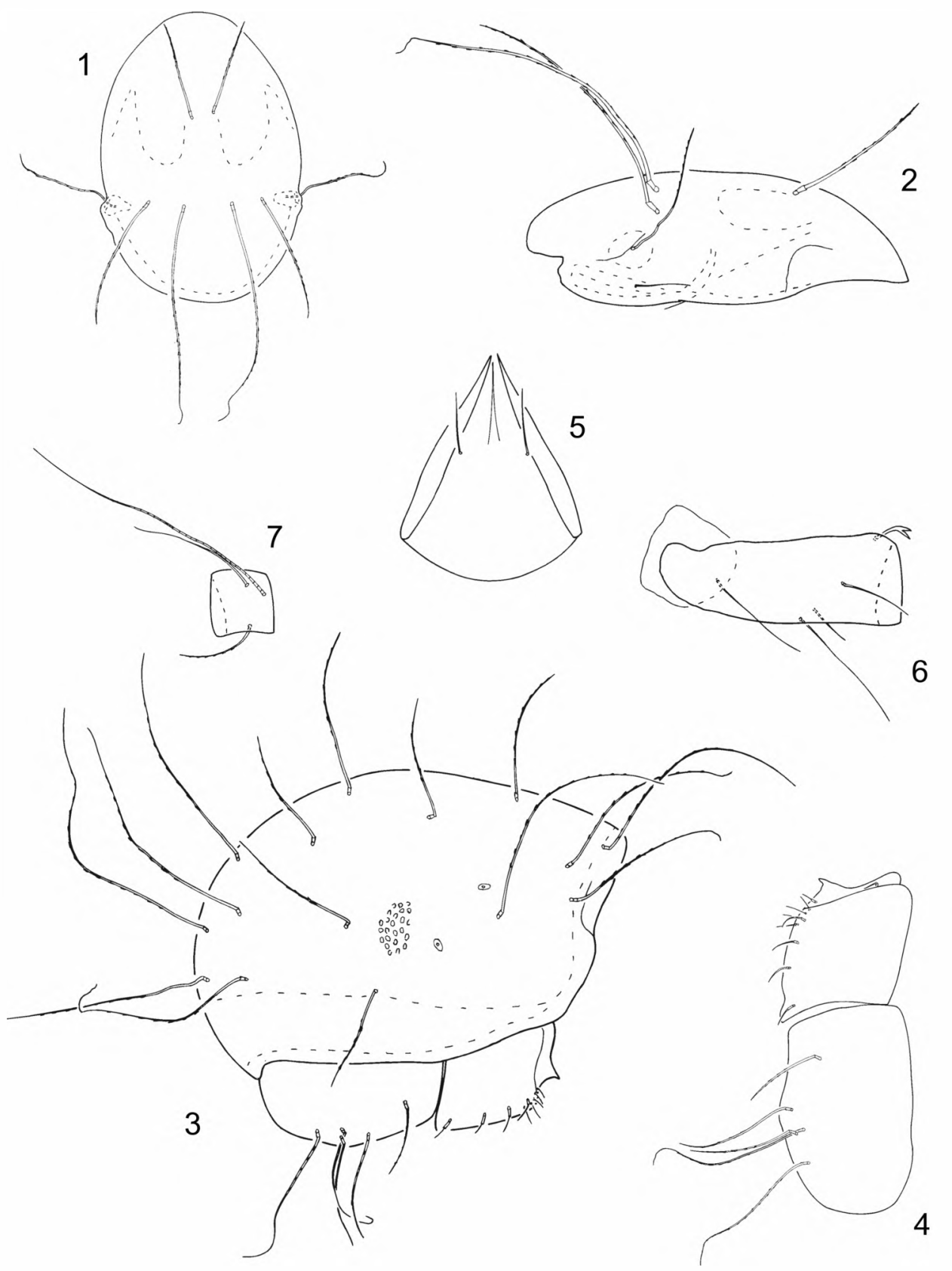

Figs 1-7. Plonaphacarus trojani sp. nov. (holotype): 1 - prodorsum, dorsal view; 2 - prodorsum, lateral view; 3 opisthosoma, lateral view; 4 - genitoaggenital and anoadanal plates; 5 - mentum of infracapitulum; 6 - trochanter and femur of leg I; 7 - tibia of leg IV. 
Chaetome of legs of "complete type", setae $d$ of femora bifurcate and located at distal end of article.

Types. Holotype and one paratype: ANIC-1525, Bruxner Park Floral Reserve, Sealy Lookout Road, $5 \mathrm{~km}$ northwest of Coffs Harbour, alt. $170 \mathrm{~m}, 30^{\circ} 15^{\prime} \mathrm{S}, 153^{\circ} 07^{\prime} \mathrm{E}$, wet sclerophyll forest, Eucalyptus pilularis litter, 18.04.1993, leg. D. S. Chandler.

Holotype in Australian National Insect Collection, CSIRO Entomology, Canberra (CSIRO), paratype in Department of Animal Taxonomy and Ecology, Faculty of Biology, Adam Mickiewicz University, Poznań, Poland (DATE).

Comparison. The new species is distinguished by the long prodorsal and notogastral setae, sensilli and setae of anoadanal plates, majority of them are flagellate. The similar Plonaphacarus aculeatus (Mahunka 1995) from Borneo has neotrichy of notogastral setae, 2832 pairs of stout setae.

Distribution. Australia.

\section{Notophthiracarus trojani sp. nov.}

(Figs 8-14)

Diagnosis. Prodorsum with prominent median crista, sensilli long, narrow covered with cilia in distal half; notogastral setae small, fine, located at small tubercules; minute setae of anoadanal plates, adanal setae situated near proximal margin.

Description. Measurements of holotype: prodorsum: length 394, width 278, height 214 , sensillus 101, setae: interlamellar 18, lamellar 13, rostral 38, exobothridial 13; notogaster: length 727 , width 505 , height 434 , setae: $c_{1} 56, h_{1} 30, p_{1} 40$; genitoaggenital plate $190 \times 164$; anoadanal plate $177 \times 126$.

Colour brown. Surface of the prodorsum covered with foveae. Surface of notogaster with irregular furrows.

Prodorsum with prominent median crista. Lateral carinae absent. Sigillar fields not discerned. Posterior furrows long and well discernible. Sensilli long, narrow, bent in proximal end, covered with small cilia in distal half. Setae small, filiform, smooth.

Notogaster with well marked tubercules, each tubercule bears one seta. Total number of setae is 15 pairs, all fine, smooth, small $\left(c_{1} / c_{1}-d_{1}=0.3\right)$. Setae $c_{1-3}$ remote from anterior margin, setae $c_{1}$ and $c_{2}$ more than setae $c_{3}$. Vestigial setae not observed. Two pairs of lyrifissures, ia and im, present.

Ventral region. Mentum of infracapitulum with seatae $h$ slightly shorter than distance between them. Arrangement of genital setae $6: 3$. Anoadanal plates with 5 pairs of setae. All anal and adanal setae minute, adanal setae situated near proximal border af plates.

Legs setation of "complete type". Seta $d$ on femora I distinctly remote from distal end of segment.

Types. Holotype and 7 paratypes: ANIC-564, Credition Ck., Eungella N. P., $760 \mathrm{~m}$, $21^{\circ} 09^{\prime} \mathrm{S}, 148^{\circ} 30^{\prime} \mathrm{E}$, rainforest, 11.11.1976, leg. R. W. Taylor and T. A. Weir.

Holotype and three paratypes in CSIRO, four paratypes in DATE.

Comparison. The new species is very similar to Notophthiracarus admirabilis Niedbała \& Colloff, 1997 by the shape of prodorsum with the prominent median carina, small and fine setae of body, formula of genital setae 6: 3, small setae of anoadanal plate, adanal situated near paraxial border. The principal differences are the presence of notogastral tubercules bearing the setae and shape of sensilli, long, narrow, covered with cilia.

Distribution. Australia. 

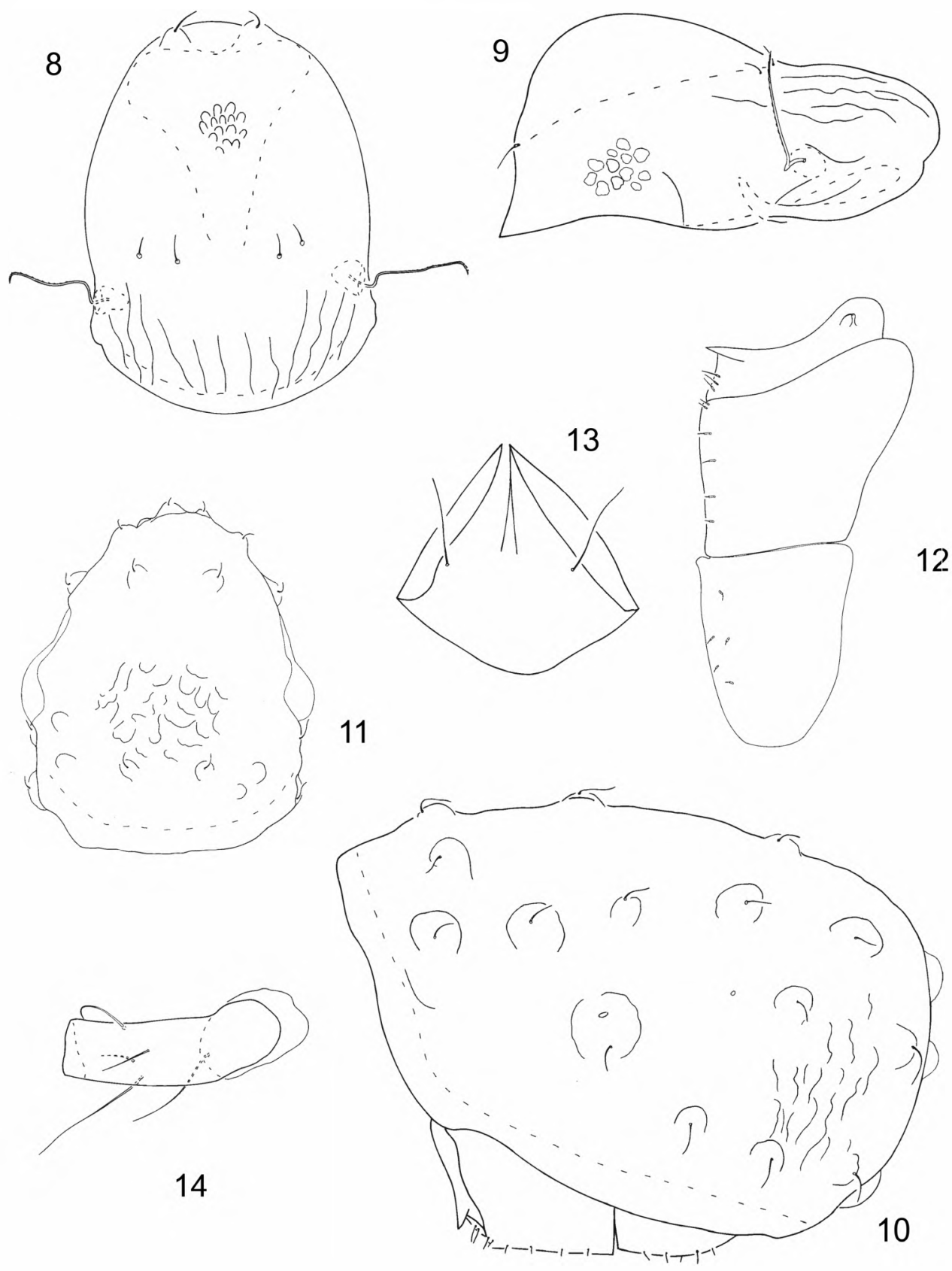

Figs 8-14. Notophthiracarus trojani sp. nov. (holotype): 8 - prodorsum, dorsal view; 9 - prodorsum, lateral view; 10 opisthosoma, lateral view; 11 - opisthosoma, dorsal view; 12 - genitoaggenital and anoadanal plates; 13 - mentum of infracapitulum; 14 - trochanter and femur of leg I. 


\section{REFERENCES}

NiEdBazA W. 2000. The ptyctimous mites fauna of the Oriental and Australian regions and their centres of origin (Acari: Oribatida). Genus, Suppl. 10, 493 pp.

NIEDBAEA W. 2006. Supplement to the knowledge of ptyctimous mites (Acari: Oribatida) from Australian Region. Annales Zoologici, 56 (Suppl. 1): 99-156.

Norton R. A. \& Behan-Pelletier V. 2009. Suborder Oribatida. In: Kranz G. W.\& Walter D. E. (eds), A manual of Acarology. Third Edition, pp. 430-564. Texas Tech University Press, 704 pp.

\section{STRESZCZENIE}

[Dwa nowe gatunki roztoczy (Acari, Oribatida, Phthiracaroidea, Steganacaridae) z Australii]

Dwa nowe gatunki z Australii: Plonaphacarus trojani sp. nov. i Notophthiracarus trojani sp. nov. są dedykowane, w rocznicę 80 urodzin, znakomitemu ekologowi i entomologowi polskiemu Prof. dr Przemysławowi Trojanowi.

Nowoopisywane gatunki należą do dwóch typowych dla południowej półkuli rodzajów Steganacaridae: Plonaphacanus Niedbala i Notophthiracarus Ramsay. W Australii Notophthiracarus jest reprezentowany przez dużą liczbę, ponad 60 gatunków, natomiast Plonaphacarus tylko przez dziewięć gatunków. 